\title{
Peran Kompensasi Terhadap Motivasi Karyawan (Studi Kasus di ITS)
}

\author{
Rio Haryo Wicaksono, Bustanul Arifin Nur dan Yani Rahmawati \\ Jurusan Manajemen Bisnis, Fakultas Teknik Industri, Institut Teknologi Sepuluh Nopember (ITS) \\ Jl. Arief Rahman Hakim, Surabaya 60111 Indonesia \\ e-mail: nooneknows468@yahoo.com
}

\begin{abstract}
Abstrak-Penelitian ini berdasarkan observasi di berbagai unit ITS terdapat banyak karyawan yang masuk kerja tidak sesuai dengan jam yang telah ditentukan dan juga pada saat waktu di luar jam istirahat banyak karyawan yang menggunakan jam kerjanya dilakukan untuk beristirahat. Penelitian ini termasuk penelitian eksplanatori dengan menggunakan distribusi kuesioner. Populasi dalam penelitian ini 1194 staf. Teknik pengambilan sampel dalam penelitian ini yaitu stratified random sampling. Penggunaan sampel karyawan minimum 3 orang staf di setiap unit organisasi ITS. Data dikumpulkan dengan kuesioner yang telah diuji validitas dan reliabilitasnya. Teknik analisis pengukuran variabel menggunakan skala likert. Pengumpulan data yang valid berupa Kuesioner - kuesioner yang selanjutnya diolah dengan menggunakan analisa deskriptif untuk melihat apakah faktor kompensasi berperan pada motivasi kerja karyawan ITS. Berdasarkan analisa ditemukan bahwa faktor kompensasi kenaikan jabatan merupakan faktor yang berperan paling tinggi dalam mempengaruhi motivasi karyawan, sedangkan faktor kesempatan merupakan faktor motivasi yang paling tinggi di ITS.
\end{abstract}

Kata Kunci-ITS, Karyawan, Kompensasi, Motivasi

\section{PENDAHULUAN}

$\mathrm{S}$ ETIAP organisasi swasta ataupun pemerintah dituntut untuk dapat mengoptimalkan sumber daya manusia dan bagaimana sumber daya manusia dikelola. Para ahli praktisi manajemen mengakui bahwa sumber daya manusia merupakan faktor penting dalam perusahaan. Menurut Hariandja (2002) Sumber Daya Manusia (SDM) merupakan salah satu faktor yang sangat penting selain faktor modal, oleh karena SDM harus dikelola dengan baik untuk meningkatkan efektivitas dan efisiensi organisasi. Pengelolaan sumber daya manusia tidak lepas dari faktor karyawan yang diharapkan dapat berprestasi sebaik mungkin demi mencapai tujuan organisasi. Karyawan merupakan aset utama organisasi dan mempunyai peran yang strategis didalam organisasi yaitu sebagai pemikir, perencana, dan pengendali aktivitas organisasi. Menurut [1], motivasi adalah rangsangan, dorongan ataupun pembangkit tenaga yang dimiliki seseorang atau sekolompok masyarakat yang mau berbuat dan bekerjasama secara optimal dalam melaksanakan sesuatu yang telah direncanakan untuk mencapai tujuan yang telah ditetapkan. Demi tercapainya tujuan organisasi, karyawan memerlukan motivasi untuk bekerja lebih rajin. Melihat pentingnya karyawan dalam organisasi, maka karyawan diperlukan perhatian lebih serius terhadap tugas yang dikerjakan sehingga tujuan organisasi tercapai. Dengan motivasi kerja yang tinggi, karyawan akan bekerja lebih giat di dalam melaksanakan pekerjaannya, sebaliknya dengan motivasi kerja yang rendah karyawan tidak mempunyai semangat bekerja, mudah menyerah, dan kesulitan dalam menyelesaikan pekerjaannya Total karyawan yang dimiliki oleh ITS adalah 2154 orang, yang terdiri dari 960 tenaga pendidik dan 1194 tenaga kependidikan.

Berdasarkan web resmi ITS, perguruan tinggi ini memiliki visi untuk menjadi perguruan tinggi dengan reputasi internasional dalam ilmu pengetahuan, teknologi dan seni terutama menunjang industri dan kelautan yang berwawasan lingkungan. Misi ITS adalah memberikan kontribusi nyata dalam pengembangan ilmu pengetahuan, teknologi, dan seni untuk kesejahteraan masyarakat melalui kegiatan - kegiatan pendidikan, penelitian, pengabdian kepada masyarakat dan pengelolaan sistem berbasis Teknologi Informasi dan Komunikasi. Melihat visi dan misi ITS maka dapat disimpulkan bahwa kunci utama dalam melaksanakan misi dan mencapai visi adalah sumber daya manusianya. Menurut visi dan misi tersebut ITS sangat berharap bahwa karyawan yang bekerja di perguruan tinggi ini memiliki kemampuan yang mumpuni dan berdedikasi tinggi sehingga mampu untuk mencapai visi yang ditetapkan dengan melaksanakan misi yang juga telah ditetapkan sehingga terdapat hubungan yang selaras antara pelaksanaan dan pencapaian.

Berdasarkan hasil survey pendahuluan yang dilakukan penulis pada tanggal 3 Oktober 2016 dengan menggunakan metode wawancara kepada beberapa karyawan ITS, diperoleh informasi bahwa terdapat beberapa karyawan yang tidak puas dengan sistem kompensasi yang diberikan oleh ITS sehingga membuat motivasi kerja para karyawan menurun, hal ini ditemukan pada saat peneliti mengobservasi beberapa unit organisasi di ITS, terdapat beberapa karyawan yang tidak masuk sesuai jam kerja yang ditentukan ada juga beberapa karyawan ITS yang masih menggunakan jam kerja sebagai jam istirahat, padahal jam istirahat yang telah ditentukan oleh ITS telah habis. Sementara itu hasil dari wawancara tentang motivasi kerja diketahui terdapat karyawan yang mengatakan bahwa mereka bekerja sebatas mencari pengalaman kerja dan mengumpulkan dana untuk membangun sebuah usaha sendiri. Hal ini menjadi salah satu alasan bagi peneliti untuk melakukan penelitian di ITS, apabila ITS berhadapan dengan persoalan yang kasat mata (visible), barangkali tidak terlalu sulit untuk melakukan langkah antisipatif terhadap persoalan tersebut, 
akan tetapi apabila ITS berhadapan dengan persoalan motivasi dari tenaga kerjanya, maka langkah penyelesaiannya menjadi tidak mudah karena motivasi terkait dengan sesuatu yang tidak dapat dilihat dengan kasat mata (invisible), maka salah satu aspek yang menarik untuk diteliti adalah peran kompensasi terhadap motivasi karyawan ITS.

\section{KAJIAN PUSTAKA}

\section{A. Penjelasan}

Salah satu tujuan manajemen sumber daya manusia, yaitu memastikan organisasi memiliki tenaga kerja yang bermotivasi dan berkinerja tinggi, serta dilengkapi dengan saran untuk menghadapai perubahan yang dapat memenuhi kebutuhan karyawannya. Salah satu caranya adalah melalui kompensasi.

Menurut [5] kompensasi dapat diartikan sebagai seperangkat bentuk imbalan yang diberikan oleh organisasi kepada karyawan sebagai balas jasa atas pekerjaan yang mereka lakukan. Kompensasi akan tampak adanya apabila pertukaran dimana seseorang memberikan kemampuannya pada organisasi dan organisasi memberikan imbalan sehingga organisasi dapat mencapai tujuan dengan bantuan karyawan. Berdasarkan definisi kompensasi tersebut, maka dapat disimpulkan bahwa kompensasi merupakan imbalan yang wajib diberikan organisasi kepada karyawan atas kontribusi mereka kepada perusahaan, dan dalam pembayaran harus sesuai dengan peraturan yang berlaku di wilayah tersebut serta perjanjian kedua belah pihak.

Motivasi berasal dari kata latin movere yang berarti dorongan, keinginan, sebab, atau alasan seseorang melakukan sesuatu. Menurut Manullang (1982), motivasi adalah pemberian kegairahan bekerja kepada karyawan, dengan pemberian motivasi dimaksudkan pemberian daya perangsang kepada karyawan yang bersangkutan agar karyawan tersebut bekerja dengan segala upayanya. Menurut Handoko (1999), motivasi diartikan sebagai keadaan dalam pribadi seseorang yang mendorong keinginan individu untuk melakukan kegiatan - kegiatan tertentu guna tujuan. Menurut Mathis (2006), motivasi adalah keinginan dalam diri seseorang yang menyebabkan orang tersebut bertindak. Biasanya orang bertindak karena suatu alasan untuk mencapai tujuan. Memahami motivasi sangatlah penting karena kinerja, reaksi terhadap kompensasi dan persoalan sumber daya manusia yang lain dipengaruhi dan mempengaruhi motivasi. Pendekatan untuk memahami motivasi berbeda - beda karena teori yang berbeda mengembangkan pandangan dan model mereka sendiri.

Teori motivasi manusia diperkenalkan oleh psikolog Abraham Maslow yang menyatakan bahwa orang - orang atau individu termotivasi untuk berperilaku dalam pekerjaannya untuk memenuhi kebutuhannya yang terdiri dari 5 tingkatan kebutuhan. Kelima tingkatan kebutuhan itu adalah kebutuhan fisik (physical needs), kebutuhan keamanan (safety and security needs), kebutuhan social (social needs), kebutuhan penghargaan (esteem needs) dan kebutuhan aktualisasi diri (self actualization needs). Kebutuhan seseorang merupakan dasar untuk model motivasi. Kebutuhan adalah kekurangan yang dirasakan oleh seseorang pada saat tertentu yang menimbulkan tegangan yang menyebabkan timbulnya keinginan. Karyawan akan berusaha semaksimal mungkin untuk menutupi kekurangannya dengan melakukan suatu aktivitas yang lebih baik dalam melaksanakan pekerjaannya.

Menurut [2] motivasi adalah sesuatu yang mendorong seseorang untuk menunjukkan perilaku tertentu. Perilaku yang diharapkan untuk ditunjukkan oleh tenaga kerja di perusahaan tentunya perilaku yang akan menghasilkan kinerja terbaik bagi perusahaan dan tentunya bukan sebaliknya. Kinerja terbaik menurut [3] ditentukan oleh 3 faktor, yaitu motivasi, kemampuan dan lingkungan kerja. Motivasi yaitu yang terkait dengan keinginan untuk melakukan pekerjaan. Kemampuan yaitu kapabilitas dari tenaga kerja atau SDM untuk melakukan pekerjaan. Lingkungan pekerjaan yaitu sumber daya dan situasi yang dibutuhkan untuk melakukan pekerjaan tersebut.

Berdasarkan definisi motivasi beberapa ahli di atas, maka dapat disimpulkan bahwa motivasi merupakan keinginan yang timbul dalam diri karyawan yang berasal dari dalam dirinya sendiri maupun berasal dari luar dirinya, baik yang berasal dari lingkungan kerjanya maupun dari luar lingkungan kerjanya. Motivasi bukanlah merupakan sesuatu yang berdiri sendiri, melainkan ada beberapa faktor yang mempengaruhinya.

\section{METODE PENELITIAN}

\section{A. Identifikasi Masalah}

Berdasarkan observasi di lapangan di mana peneliti menemukan penyimpangan terhadap aturan kerja yang dilakukan oleh karyawan ITS, yaitu masuk tidak sesuai dengan jam kerja yang telah ditentukan, selain itu juga ditemukan karyawan yang masih menggunakan jam kerja sebagai jam istirahat dan sebetulnya hal - hal tersebut tidak boleh dilakukan selama jam kerja masih berlangsung.

\section{B. Konsep dan Model Penelitian}

Penelitian ini termasuk dalam kategori penelitian eksplanatori karena penelitian ini bertujuan untuk menguji pengaruh kompensasi terhadap motivasi kerja karyawan di ITS. Teknik yang digunakan dalam pengambilan datanya menggunakan distribusi kuesioner yang berupa sejumlah pertanyaan yang diberikan kepada responden untuk diisi sesuai keadaan yang sebenarnya.

\section{Populasi dan Sampel}

Penelitian ini termasuk dalam kategori penelitian eksplanatori karena penelitian ini bertujuan untuk menguji pengaruh kompensasi terhadap motivasi kerja karyawan di ITS. Teknik yang digunakan dalam pengambilan datanya menggunakan distribusi kuesioner yang berupa sejumlah pertanyaan yang diberikan kepada responden untuk diisi sesuai keadaan yang sebenarnya. Populasi dalam penelitian ini adalah seluruh karyawan ITS yang berjumlah 1194 orang. Peneliti memilih sampel secara acak minimal 3 orang karyawan dari tiap unit organisasi di ITS. 


\section{Teknik Pengambilan Sampel}

Peneliti menggunakan stratified random sampling sebagai teknik pengambilan sampel. Stratified random sampling adalah mengelompokkan seluruh populasi dengan kriteria tertentu dalam beberapa unit bagian populasi. Setiap elemen yang ada di dalam populasi hanya boleh dimasukkan ke dalam satu unit. Setiap unit berfungsi sebagai tempat pemilihan sampel. Setiap unit sampel akan ada yang dipilih secara acak untuk menjadi sampel.

\section{E. Variabel Penelitian}

Variabel merupakan segala bentuk sesuatu yang ditetapkan peneliti untuk dipelajari sehingga diperoleh informasi yang dibutuhkan kemudian dapat ditarik kesimpulannya. Variabel penelitian dapat dilihat pada gambar 1 .

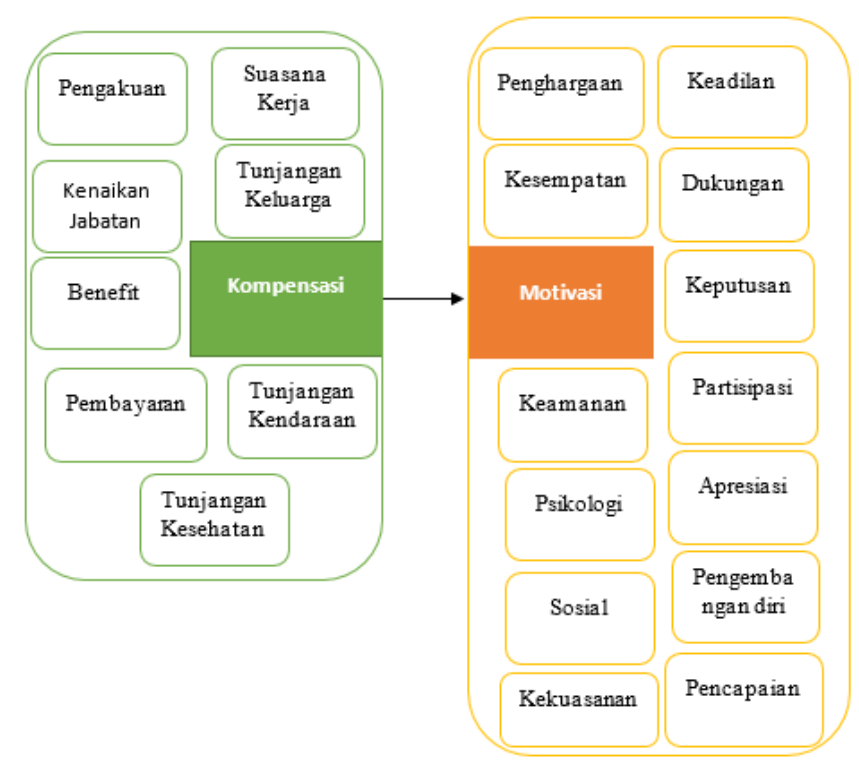

Gambar 1. Variabel Penelitian.

Sumber: [4], [6] dan [7]

\section{PENGUMPULAN DATA}

Pengumpulan data menggunakan kuesioner dan wawancara. Seluruh kuesioner yang dibuat telah disebar ke hampir semua unit organisasi di ITS yang berjumlah 45 unit, namun ada beberapa tempat yang belum dicapai dalam penyebarannya yaitu UPT Kearsipan dan UPT Kerjasama dan Hubungan Internasional. Penyebaran dilakukan dengan memberikan tiga buah kuesioner ke setiap unit organisasi. Peneliti menargetkan untuk memberikan tiga buah kuesioner untuk setiap unit organisasi, yang berarti setiap unit organisasi membutuhkan tiga responden untuk mengisi kuesioner tersebut, apabila ditotal secara keseluruhan, penliti membutuhkan 135 responden dari 45 unit organisasi dalam penelitiannya, namun faktanya peneliti hanya berhasil mendapatkan 129 responden dari 135 responden yang dibutuhkan. Sisa 6 responden lainnya belum dapat dicapai oleh peneliti, karena terdapat kendala berupa waktu penelitian yang diberikan kepada peneliti tidak cukup.

Kenaikan jabatan memiliki nilai yang sangat berarti karena merupakan bukti pengakuan atas hasil atau prestasi kerja karyawan. Seorang karyawan pasti mengharapkan adanya peningkatan - peningkatan dalam karirnya, salah satu cara agar seorang karyawan dapat meningkatkan karirnya yaitu melalui jenjang promosi yang ada di perusahaan tempat karyawan tersebut bekerja. Jenjang promosi dapat menambah semangat dan gairah karyawan di dalam bekerja, sehingga karyawan akan bekerja dengan penuh motivasi untuk mendapatkan promosi dalam karirnya. Apabila seorang karyawan memperoleh promosi, maka jabatan dan kompensasi yang akan diterima secara otomatis juga akan meningkat, hal ini akan dapat menimbulkan kepuasan kerja yang lebih dari yang sebelumnya.

\section{PEMBAHASAN}

Diagram Indikator Kompensasi

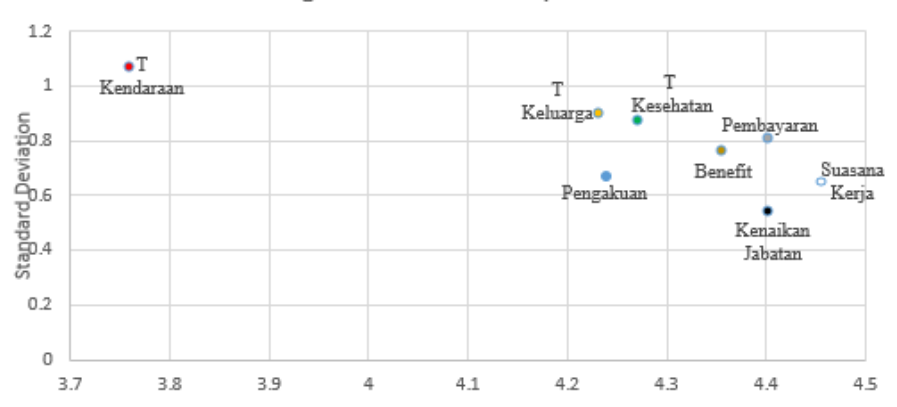

Gambar 2. Diagram Indikator Kompensasi

Tunjangan kendaraan memiliki nilai standar deviasi tertinggi yang mengindikasikan bahwa tunjangan kendaraan merupakan hal yang paling tidak dominan diantara semua indikator kompensasi, padahal tunjangan kendaraan diberikan untuk mendukung produktivitas kerja dan mewujudkan asas keadilan di suatu perusahaan, perusahaan memberikan tunjangan transportasi kepada karyawan juga untuk memicu semangat kehadiran karyawan untuk bekerja, namun bagi staf ITS tunjangan ini hanya didapatkan apabila staf tersebut telah memiliki jabatan yang tinggi.

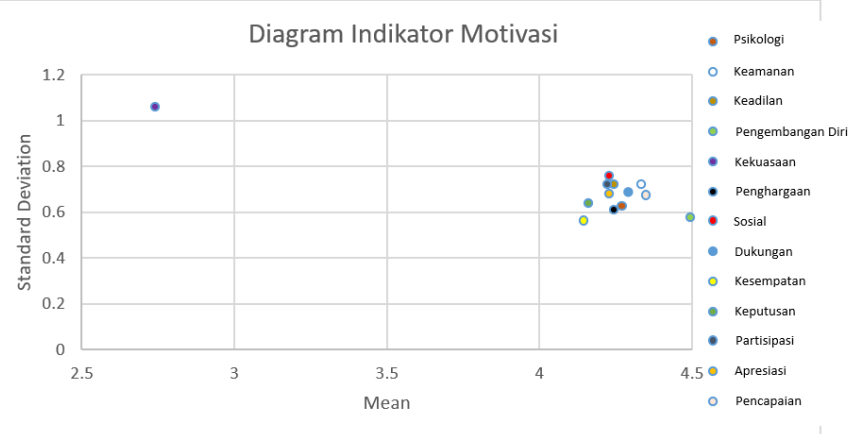

Gambar 3. Diagram Motivasi

kesempatan mendapatkan nilai standar deviasi terendah yang berarti tingkat homogenitasnya tinggi dan kekuasaaan mendapatkan nilai rata - rata terendah, dapat disimpulkan bahwa kesempatan merupakan indikator motivasi paling dominan diantara yang lain, yang berarti motivasi utama bagi karywan ITS untuk bekerja adalah untuk mendapatkan kesempatan.

Salah satu cara untuk mendorong pengembangan diri adalah dengan memberikan kesempatan untuk terlibat dalam bekerja, 
dengan membantu melibatkan karyawan dapat menumbuhkan kebahagiaan dan persepsi, bahwa kerja merupakan aspek sesuatu yang menyenangkan. Motivasi dari karyawan ITS dalam bekerja bukanlah mencari kekuasaan, namun lebih condong terhadap indikator indikator lainnya. Sebenarnya karyawan yang termotivasi oleh kekuasaan memiliki keinginan kuat untuk menjadi berpengaruh dan mengendalikan. Mereka ingin pandangan dan ide-ide mereka harus mendominasi dan dengan demikian, mereka ingin memimpin. Individu tersebut termotivasi oleh kebutuhan untuk reputasi dan harga diri.

\section{KESIMPULAN DAN SARAN}

Berdasarkan penelitian maka dapat disimpulkan bahwa variabel kompensasi mempunyai peran terhadap variabel motivasi, hal ini dapat dilihat dari nilai mean dan standad deviation dari setiap indikator dari masing - masing variabel.

Berdasarkan penelitian maka saran yang bisa diberikan untuk peneliti selanjutnya adalah peneliti selanjutnya dapat mengambil dengan objek yang berbeda serta mempertimbangkan faktor gaya kepemimpinan.

\section{DAFTAR PUSTAKA}

[1] Azwar. S, “Sikap Manusia: Teori dan Pengukuran”, Yogyakarta: Liberty (2000)

[2] Freeman. R. E, dan Gilbert. D. R, "Management, edisi keenam”, New Jersey: Prentice Hall Inc. (1995)

[3] Griffin. R, "Management, edisi kedua", Jakarta: Erlangga (2000)

[4] Negash. R, Zewude. S, dan Megersa. R, "The effect of compensation on employees motivation in Jimma University academic staff', BASIC RESEARCH JOURNALS., vol. 3, no. 2, hal, 17-27. (2014)

[5] Panggabean. S, "Manajemen Sumber Daya Manusia", Bogor: Ghalia Indonesia (2004)

[6] Rizal. M, Idrus. M. S, Djumahir dan Mintarti. R, "Effect of Compensation on Motivation, Organizational Commintment and Employee Performance (Studies at Local Revenue Management in Kendari City)", International Journal of Business and Management Invention., vol. 3, no. 2, hal, 64-79. (2014)

[7] Sudarno. Priyono. dan Sukmaningrum. D, "Effect of Compensation, Motivation, and Organizational Climate on Employee Satisfaction: Study on PT. Sumber Alfaria Trijaya Tbk. In Gedangan-Sidoarjo", International Journal of Business and Management., vol. 11, no. 2, hal, 212-220. (2016) 